\title{
Yeasts associated with the curculionid beetle Xyloterinus politus: Candida xyloterini sp. nov., Candida palmyrensis sp. nov. and three common ambrosia yeasts
}

\author{
Sung-Oui Suh and Jianlong Zhou
}

Correspondence

Sung-Oui Suh

ssuh@atcc.org

\author{
Mycology and Botany Program, American Type Culture Collection, 10801 University Blvd, \\ Manassas, Virginia 20110, USA
}

\begin{abstract}
Seven yeast strains were isolated from the body surface and galleries of Xyloterinus politus, the ambrosia beetle that attacks black oak trees. Based on rDNA sequence comparisons and other taxonomic characteristics, five of the strains were identified as members of the species Saccharomycopsis microspora, Wickerhamomyces hampshirensis and Candida mycetangii, which have been reported previously as being associated with insects. The remaining two yeast strains were proposed as representatives of two novel species, Candida xyloterini sp. nov. (type strain ATCC $62898^{\top}=\mathrm{CBS} 11547^{\top}$ ) and Candida palmyrensis sp. nov. (type strain ATCC $62899^{\top}=$ CBS $11546^{\top}$ ). C. xyloterini sp. nov. is a close sister taxon to Ogataea dorogensis and assimilates methanol as a sole carbon source but lacks ascospores. On the other hand, C. palmyrensis sp. nov. is phylogenetically distinct from any other ambrosia yeast reported so far. The species was placed near Candida sophiae-reginae and Candida beechii based on DNA sequence analyses, but neither of these were close sister taxa to C. palmyrensis sp. nov.
\end{abstract}

As lignified cellulose, the major component of wood, is not easily digested by most insects, fungi that colonize wood serve as ambrosia for certain beetle groups (Batra, 1966; Harrington, 2005). Several phylogenetically distinct yeasts and filamentous fungi have been reported as ambrosia fungi. For example, it is well known that species of the genus Ambrosiozyma can be isolated from sources associated with bark or ambrosia beetles (van der Walt, 1972; Smith, 1998). Several mitosporic yeasts, such as Candida mycetangii, Candida kashinagacola and Candida pseudovanderkliftii, have also been isolated directly from beetles or their galleries (Kurtzman, 2000; Endoh et al., 2008b).

In the 1980s, the ATCC Mycology Collection acquired seven unidentified yeast strains that were associated with Xyloterinus politus (Coleoptera: Curculionidae), the ambrosia beetle that attacks black oak (Haanstad \& Norris, 1985). These strains were recently characterized phenotypically and genotypically; their taxonomy and molecular phylogeny are reported here and their ecological roles compared with those of other previously discovered ambrosia yeasts are discussed.

Abbreviation: ITS, internal transcribed spacer.

The GenBank/EMBL/DDBJ accession numbers for the rDNA sequences from this study are as follows: FJ381686-FJ381692 for the SSU rDNA; FJ381693-FJ381699 for ITS regions and 5.8S rDNA; and FJ381700-FJ381706 for D1/D2 regions of the LSU rDNA.

\section{Yeast strains and identification}

All the yeast strains used in this study were isolated from both the adult females of Xyloterinus politus (Coleoptera: Curculionidae) and their galleries in black oak collected in Palmyra, Wisconsin, USA, by Haanstad \& Norris (1985). Seven yeast strains were deposited at the ATCC in 1987 and were assigned the accession numbers ATCC 62895-ATCC 62901. Morphological observations and metabolic tests were performed according to established methods (Yarrow, 1998; Barnett et al., 2000). Assimilation tests for carbon and nitrogen compounds were performed in liquid media. The yeasts were observed on YM agar, $2 \%$ malt agar, cornmeal agar and V8 juice agar at 15,25 and $30{ }^{\circ} \mathrm{C}$ for up to 6 weeks to determine ascospore formation.

\section{DNA sequencing and sequence analyses}

Nucleic acids were extracted and purified following the procedures of Lee \& Taylor (1990). The primer sets NS1/ NS8, ITS5/ITS4 and LR0R/LR5 were used for PCR amplification of nuclear rRNA gene (rDNA) repeats (White et al., 1990; Hausner et al., 1993). PCR products were purified using Quantum Prep PCR Kleen spin columns (Bio-Rad Laboratories) and the purified PCR products were used as templates for sequencing with an ABI PRISM BigDye Terminator cycle sequencing kit v.3.1 
(PE Applied Biosystems). The complete sequences of SSU rDNA, internal transcribed spacer (ITS) regions including $5.8 \mathrm{~S} \mathrm{rDNA}$ and the D1/D2 region of LSU rDNA were obtained with primers NS1, NS2, NS4, NS8, ITS1, ITS4, LR0R and LR3 using an ABI 3130xl automated DNA sequencer. Sequences from newly isolated yeasts were compared with those of other yeasts in GenBank by using the BLAST search program (Altschul et al., 1990). Selected DNA sequences were aligned with the multialignment program CLUSTAL_X (Thompson et al., 1997) and optimized visually. Maximum-parsimony analyses were performed using PaUP 4.0b10 (Swofford, 2002). Heuristic tree searches were executed using the tree bisection-reconnection branch-swapping algorithm with random sequence analysis. Bootstrap values of the most parsimonious tree were obtained from 1000 replications. Base pair differences were counted using BLAST2 sequences (Tatusova \& Madden, 1999) or from the manually aligned sequence database.

\section{Yeast identification and novel species}

Based on phenetic characteristics from more than 80 physiological and morphological tests and phylogenetic analyses from sequences of rDNA repeats, all the yeast isolates associated with the beetle $X$. politus were identified as members of the subphylum Saccharomycotina. Ascospores were observed only from strains ATCC 62895, ATCC 62896 and ATCC 62897 on YM agar or cornmeal agar at $25{ }^{\circ} \mathrm{C}$ within 1 month (data not shown).

Strain ATCC 62895 was convincingly identified as Saccharomycopsis microspora; similarly, strains ATCC 62896 and ATCC 62897 were identified as Wickerhamomyces (=Pichia) hampshirensis, and strains ATCC 62900 and ATCC 62901 were identified as Candida mycetangii. Sequences in the D1/D2 region of the LSU rDNA were identical or had a maximum of 1 bp difference between the isolates and the type strains of each species, which indicates that these isolates are conspecific to the three species. Taxonomic placement of those isolates was also well supported by high similarities between the isolates and the three yeast species in the SSU rDNA and ITS regions, including the 5.8S rDNA, as well as in other taxonomic characteristics such as ascospore formation and results of physiological tests. However, these isolates can be distinguished from other strains in the same species published previously by some carbon and nitrogen utilization tests: strain ATCC 62895 by L-sorbose (delayed positive), ethanol $(-)$ and D-tryptophan $(+)$ utilization, and growth on $50 \%$ glucose (+); strains ATCC 62896 and ATCC 62897 by citrate $(-)$ and D-tryptophan $(-)$ utilization; and strain ATCC 62900 by myo-inositol $(+)$ utilization (Kurtzman, 1987, 1999, 2000).

Strains ATCC $62898^{\mathrm{T}}$ and ATCC $62899^{\mathrm{T}}$, on the other hand, were identified as representatives of two novel species of the genus Candida according to molecular, physiological and morphological taxonomic criteria. rDNA sequence similar- ity searches in GenBank retrieved Ogataea (=Pichia) dorogensis strains as the closest matches to strain ATCC $62898^{\mathrm{T}}$, but strain ATCC $62898^{\mathrm{T}}$ could be distinguished from this species by $6 \mathrm{nt}$ substitutions in the D1/D2 region of the LSU rDNA and by 7 nt substitutions and 1 gap in the

Table 1. Physiological characteristics of Candida xyloterini sp. nov. and Candida palmyrensis sp. nov.

Strains: 1, C. xyloterini ATCC $62898^{\mathrm{T}}$; 2, C. palmyrensis ATCC $62899^{\mathrm{T}}$. The following characteristics are invariable in both strains: fermentation of maltose $(-)$, sucrose $(-)$, methyl $\alpha$-D-glucoside $(-)$, melibiose $(-)$, lactose $(-)$, cellobiose $(-)$, melezitose $(-)$, inulin $(-)$, starch $(-)$, raffinose $(-)$ and D-xylose $(-)$; assimilation of Dglucose $(+)$, D-glucosamine $(-)$, L-arabinose $(-)$, D-arabinose $(-)$, L-rhamnose $(-)$, sucrose $(-)$, maltose $(-)$, trehalose $(+)$, methyl $\alpha$ D-glucoside $(-)$, melibiose $(-)$, lactose $(-)$, inulin $(-)$, raffinose $(-)$, melezitose $(-)$, soluble starch $(-)$, ribitol $(+)$, glycerol $(+)$, myo-inositol (-), D-glucitol $(+)$, D-mannitol $(+)$, galactitol $(-)$, citrate $(-)$, ethanol $(+)$, D-gluconate $(-)$, D-glucuronate $(-)$, Dgalacturonic acid $(-)$, propane-1,2-diol $(-)$, butane-2,3-diol (-), quinic acid $(-)$, nitrate $(-)$, nitrite $(-)$, ethylamine $(+)$, L-lysine $(+)$, cadaverine $(+)$, D-tryptophan $(-)$, creatine $(-)$, creatinine $(-)$, D-glucosamine (as nitrogen) $(-)$ and imidazole $(-)$; vitamin requirements, growth in the absence of vitamins $(-)$, myo-inositol $(+)$, pantothenate $(+)$, biotin $(+)$, thiamin $(-)$, biotin and thiamin $(-)$, pyridoxine $(+)$, pyridoxine and thiamin $(-)$, niacin $(+)$ and $p$ aminobenzoic acid $(+)$; growth at $25{ }^{\circ} \mathrm{C}(+), 30{ }^{\circ} \mathrm{C}(+)$ and $40{ }^{\circ} \mathrm{C}$ $(-)$; growth in $0.01 \%$ cycloheximide $(+)$; growth in $1 \%$ acetic acid $(-), 50 \%$ D-glucose (-), $60 \%$ D-glucose (-), $10 \% \mathrm{NaCl}(-), 16 \%$ $\mathrm{NaCl}(-)$; additional tests, starch formation $(-)$, urea hydrolysis $(-)$, Diazonium Blue B reaction $(-)$. +, Positive reaction; - , negative reaction; $\mathrm{d}$, delayed positive reaction; $\mathrm{w}$, weak positive reaction.

\begin{tabular}{|lcc|}
\hline Characteristic & $\mathbf{1}$ & $\mathbf{2}$ \\
\hline Fermentation of carbon compounds & & \\
D-Glucose & $\mathrm{d}$ & + \\
D-Galactose & - & + \\
$\alpha, \alpha$-Trehalose & $\mathrm{d}$ & + \\
Assimilation of carbon compounds & & \\
L-Arabinitol & $\mathrm{d}$ & - \\
Arbutin & + & - \\
Cellobiose & + & - \\
Erythritol & + & - \\
D-Galactose & - & + \\
D-Glucono-1,5-lactone & - & + \\
2-Keto-D-gluconate & - & + \\
DL-Lactate & - & + \\
Methanol & $\mathrm{d}$ & - \\
D-Ribose & + & - \\
Salicin & + & - \\
L-Sorbose & + & - \\
Succinate & + & + \\
Xylitol & - \\
D-Xylose & + & - \\
Growth at $37{ }^{\circ} \mathrm{C}$ & + & - \\
& + & $\mathrm{W}$ \\
\hline
\end{tabular}



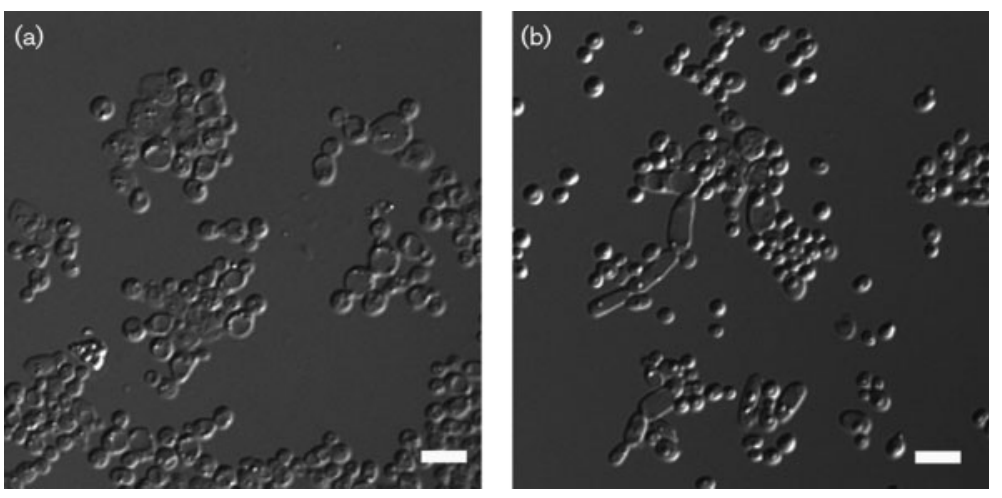

Fig. 1. Novel yeasts from ambrosia beetles. Vegetative cells of Candida xyloterini sp. nov. ATCC $62898^{\top}$ (a) and Candida palmyrensis sp. nov. ATCC $62899^{\top}$ (b) after 7 days on YM agar at $25^{\circ} \mathrm{C}$. Bars, $5 \mu \mathrm{m}$.

SSU rDNA. Physiologically, strain ATCC $62898^{\mathrm{T}}$ and $O$. dorogensis differed in their assimilation of $\mathrm{L}$-arabinose, $\mathrm{D}$ arabinose, D-glucono-1,5-lactone, succinate and citrate (Table 1; Péter et al., 2003). Strain ATCC $62898^{\mathrm{T}}$ showed several unique characteristics of the genus Ogataea such as assimilation of methanol as sole carbon source and growth at high temperatures (Table 1; Yamada et al., 1994; Nagatsuka et al., 2008), but no ascospores were observed from the strain grown for up to 6 weeks on several test media at $15-30{ }^{\circ} \mathrm{C}$. Using similar characterizations, strain ATCC $62899^{\mathrm{T}}$ was found to be significantly different from any other yeast species. The D1/D2 sequence similarity search found that strains of Candida sophiae-reginae, Debaryomyces castellii and Candida lignicola were among the highest matches in GenBank, but similarities in the D1/D2 region between strain ATCC $62899^{\mathrm{T}}$ and these species were less than $90 \%$ and these organisms are not closely related to each other phylogenetically (Kurtzman \& Robnett, 1998; Jindamorakot et al., 2007). Strain ATCC $62899^{\mathrm{T}}$ could also be clearly distinguished from the three species mentioned above based on physiological characteristics (Table 1). Ascospores were not observed from the strain grown for up to 6 weeks. Based on the molecular and other taxonomic characteristics mentioned above, two novel species, Candida xyloterini sp. nov. and Candida palmyrensis sp. nov., are proposed to accommodate strains ATCC $62898^{\mathrm{T}}$ and ATCC $62899^{\mathrm{T}}$, respectively.

\section{Latin diagnosis of Candida xyloterini Suh et Zhou sp. nov.}

Cultura in agaro extramalti et faecis continente post 7 dies ad $25{ }^{\circ} \mathrm{C}$, albida, hebes et teres. Cellulae vegetativae globosae aut subglobosae $(2.0-3.0 \times 2.0-3.0 \mu \mathrm{m})$, singulae vel binae; pseudohyphae non fiunt. Cultura in agaro cum glucose et extracto fermento et extracto malto et peptone post 10 dies ad $25{ }^{\circ} \mathrm{C}$ albida et mucoideae. Pseudohyphae et hyphae verae non fiunt. Glucosum (lente) et trehalosum (lente) fermentantur. Galactosum, maltosum, methyl $\alpha$-D-glucosidum, sucrosum, melibiosum, lactosum, cellobiosum, melezitosum, raffinosum, inulinum, amylum solubile et D-xylosum non fermentantur. Assimilantur glucosum, L-sorbosum, D-ribosum, D-xylosum, trehalosum, cellobiosum, salicinum, arbutinum, glycerolum, erythritolum, ribitolum, xylitolum, L-arabinitolum (lente), D-glucitolum, D-mannitolum, methanolum (lente) et ethanolum. Non assimilantur galactosum, D-glucosaminum, Larabinosum, D-arabinosum, L-rhamnosum, sucrosum, maltosum, methyl $\alpha$-D-glucosidum, melibiosum, lactosum, raffinosum, melezitosum, inulinum, amylum solubile, galactitolum, inositolum, gluconolactonum, 2-keto-D-gluconatum, D-gluconatum, D-glucuronatum, D-galacturonatum, DL-acidum lacticum, acidum succinicum, acidum citricum, propane-1,2diolum, butano-2,3-diolum et acidum quinicum. Assimilantur ethylaminum, L-lysinum et cadaverinum. Non assimilantur kalium nitricum, natrium nitrosum, creatinum, creatininum, glucosaminum, imidazolum et D-tryptophanum. Amylum non formatur. Thiaminum externum ad crescentiam necessarium

Fig. 2. Consensus of 64 most-parsimonious trees obtained from combined SSU rDNA and the D1/D2 region of LSU rDNA sequence data of selected yeast taxa. Neurospora crassa NRRL 13141 and Hypocrea lutea IFO 9061 (SSU rDNA) and GJS89-129 (LSU rDNA) were chosen as the outgroup taxa. The species names in the tree follow the nomenclature of Kurtzman \& Fell (1998) except for some names that have been updated by several recent taxonomic studies, e.g. Kurtzman et al. (2008), Limtong et al. (2008) and Nagatsuka et al. (2008). GenBank accession numbers after the names of yeast species are for SSU and LSU rDNA sequences, respectively. Strain NRRL Y $-2214^{\top}$ is the type strain of Pichia angusta, not Ogataea polymorpha. A to $\mathrm{D}$ on the branches indicate the major clades that include the ambrosia yeasts described in this study: $\mathrm{A}=$ Saccharomycopsis clade; $\mathrm{B}=$ Ogataea clade; $\mathrm{C}=$ Wickerhamomyces/Lindnera clade; $\mathrm{D}=$ Debaryomyces/Lodderomyces clade. Tree length $=3190$; consistency index $=0.3448$; homoplasy index $=0.6552$; retention index $=0.7301$; rescaled consistency index $=0.2518$. Numbers on tree branches indicate the percentages of bootstrap samplings derived from 1000 samples that supported the internal branches by $50 \%$ or higher. Bar, 10 changes. 


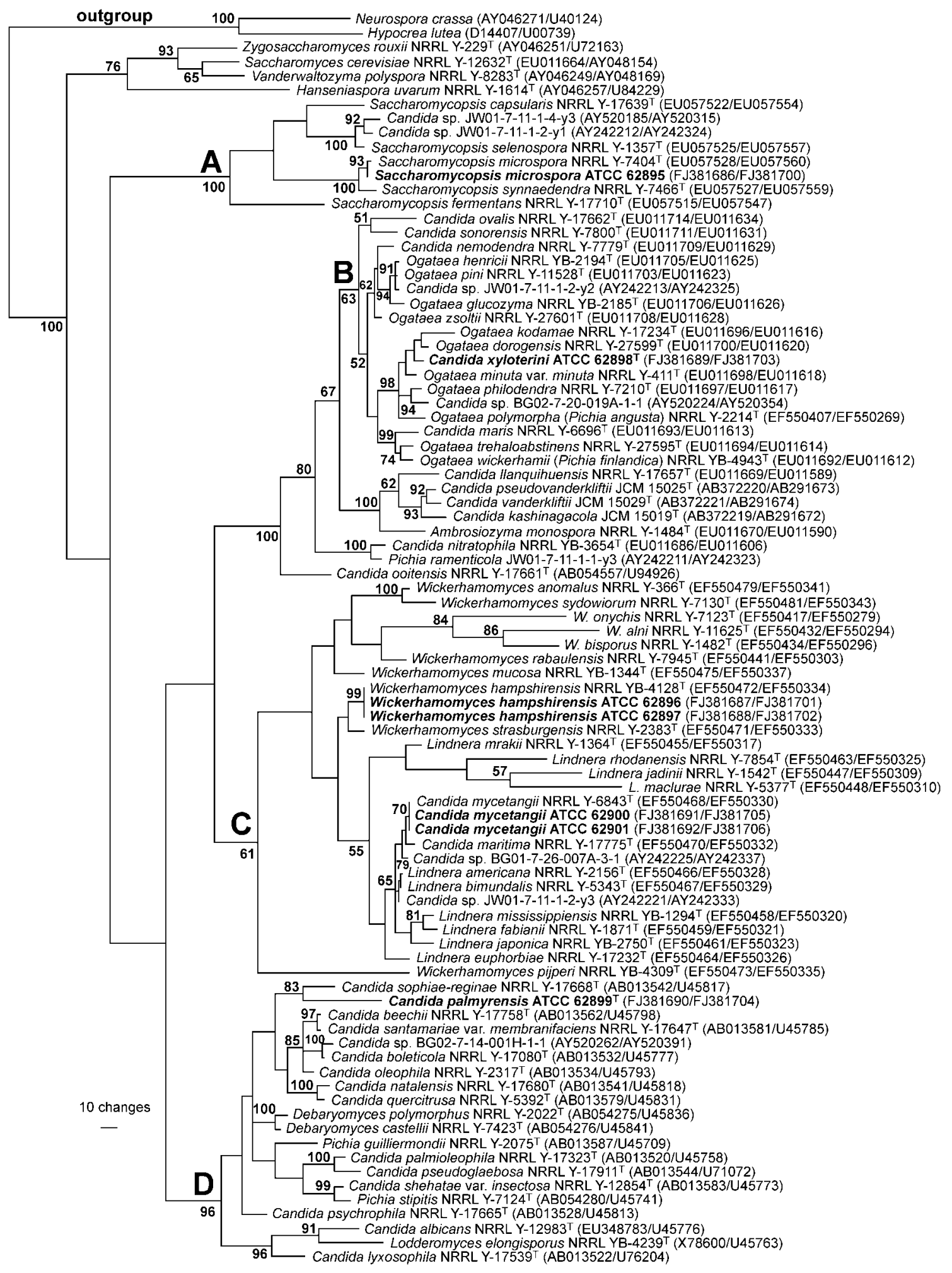

est. Augmentum fiunt in temperatura $37{ }^{\circ} \mathrm{C}$. In medio $0.01 \%$ cycloheximido addito crescit. Typus: ATCC $62898^{\mathrm{T}}$ (=CBS $11547^{\mathrm{T}}$ ) designat stirpem typicum. Isolata coleopterorum (Xyloterinus politus, Curculionidae), Palmyra, Wisconsin, USA, depositata in Collectione Culturarum ATCC (American Type Culture Collection), Manassas, Virginia, USA.

\section{Description of Candida xyloterini Suh \& Zhou sp. nov.}

Candida xyloterini (xyl.o.te.ri'ni. N.L. gen. n. xyloterini of Xyloterinus, referring to the genus name of the host beetle Xyloterinus politus). 
After 7 days growth on $\mathrm{YM}$ agar at $25{ }^{\circ} \mathrm{C}$, cells are globose to subglobose $(2.0-3.0 \times 2.0-3.0 \mu \mathrm{m})$ and occur singly or in pairs (Fig. 1a); pseudohyphae are not present and colonies are white to cream coloured, smooth, shiny, flat and slightly mucoid. After 10 days growth on malt extract agar at $25{ }^{\circ} \mathrm{C}$, colonies are white and mucoid. Pseudohyphae and septate hyphae are absent. No ascospores are observed after 6 weeks at $25{ }^{\circ} \mathrm{C}$ on YM agar, $2 \%$ malt extract agar, cornmeal agar or V8 juice agar. A summary of physiological and other characteristics is presented in Table 1.

The type strain, ATCC $62898^{\mathrm{T}}\left(=\mathrm{CBS} 11547^{\mathrm{T}}\right)$, was isolated from Xyloterinus politus (Coleoptera: Curculionidae), Palmyra, Wisconsin, USA.

\section{Latin diagnosis of Candida palmyrensis Suh et Zhou sp. nov.}

Cultura in agaro extramalti et faecis continente post 7 dies ad $25{ }^{\circ} \mathrm{C}$, albida, hebes, teres et margine ciliata. Cellulae vegetativae ellipsoideae aut fusiformes $(2.0-2.5 \times 3.0-$ $5.0 \mu \mathrm{m})$, singulae vel binae; pseudohyphae fiunt. In agaro farina Zeae maydis confecto post 10 dies ad $25^{\circ} \mathrm{C}$, pseudohyphae fiunt, hyphae verae non fiunt. Ascosporae non fiunt. Glucosum, galactosum et trehalosum fermentantur. Maltosum, methyl $\alpha$-D-glucosidum, sucrosum, melibiosum, lactosum, cellobiosum, melezitosum, raffinosum, inulinum, amylum solubile et D-xylosum non fermentantur. Assimilantur glucosum, galactosum, trehalosum, glycerolum, ribitolum, Dglucitolum, D-mannitolum, gluconolactonum, 2-keto-D-gluconatum, DL-acidum lacticum, acidum succinicum et ethanolum. Non assimilantur L-sorbosum, D-glucosaminum, D-ribosum, D-xylosum, L-arabinosum, D-arabinosum, L-rhamnosum, sucrosum, maltosum, methyl $\alpha$-D-glucosidum, cellobiosum, salicinum, arbutinum, melibiosum, lactosum, raffinosum, melezitosum, inulinum, amylum solubile, erythritolum, xylitolum, L-arabinitolum, galactitolum, inositolum, D-gluconatum, D-glucuronatum, D-galacturonatum, acidum citricum, methanolum, propane-1,2-diolum, butano-2,3-diolum et acidum quinicum. Assimilantur ethylaminum, L-lysinum et cadaverinum. Non assimilantur kalium nitricum, natrium nitrosum, creatinum, creatininum, glucosaminum, imidazolum et Dtryptophanum. Amylum non formatur. Thiaminum externum ad crescentiam necessarium est. Augmentum fiunt in temperatura $37{ }^{\circ} \mathrm{C}$ (infirme). In medio $0.01 \%$ cycloheximido addito crescit. Typus: ATCC $62899^{\mathrm{T}}\left(=\mathrm{CBS} 11546^{\mathrm{T}}\right)$ designat stirpem typicum. Isolata coleopterorum (Xyloterinus politus, Curculionidae), Palmyra, Wisconsin, USA, depositata in Collectione Culturarum ATCC, Manassas, Virginia, USA.

\section{Description of Candida palmyrensis Suh \& Zhou sp. nov.}

Candida palmyrensis (pal.my.ren'sis. N.L. fem. adj. palmyrensis referring to Palmyra, Wisconsin, USA, the area where the type strain was collected).

After 7 days growth on $\mathrm{YM}$ agar at $25^{\circ} \mathrm{C}$, cells are ellipsoidal to fusiform $(2.0-2.5 \times 3.0-5.0 \mu \mathrm{m})$ and occur singly, in pairs or in short chains (Fig. 1b); pseudohyphae are present and colonies are white to cream coloured, smooth on the top and wrinkled on the edge with irregular margins. After 10 days growth on cornmeal agar at $25{ }^{\circ} \mathrm{C}$, pseudohyphae are present and septate hyphae are absent; colonies are white, shiny and smooth with filamentous margins. No ascospores are observed after 6 weeks at $25^{\circ} \mathrm{C}$ on YM agar, $2 \%$ malt extract agar, cornmeal agar or V8 juice agar. See Table 1 for a summary of physiological and other characteristics.

The type strain, ATCC $62899^{\mathrm{T}}\left(=\mathrm{CBS} 11546^{\mathrm{T}}\right)$, was isolated from Xyloterinus politus (Coleoptera: Curculionidae), Palmyra, Wisconsin, USA.

\section{Molecular phylogeny and ecology of ambrosia yeasts}

A phylogenetic tree was constructed from the combined SSU and LSU rDNA (about $2400 \mathrm{bp}$ ) sequence data of 88 yeast taxa, including the strains reported in this study (Fig. 2). The seven ambrosia yeasts were placed into four different phylogenetic clades, indicated by A to D in Fig. 2.

W. hampshirensis ATCC 62896 and ATCC 62897, and C. mycetangii ATCC 62900 and ATCC 62901 were located in the Wickerhamomyces/Lindnera clade (clade C in Fig. 2; Kurtzman et al., 2008) and showed close relationships to their type strains, $W$. hampshirensis NRRL YB- $4128^{\mathrm{T}}$ and C. mycetangii NRRL Y-6843 ${ }^{\mathrm{T}}$, respectively. Strains of $C$. mycetangii were first isolated from mycetangia, the fungusinhabiting organ of ambrosia beetles (Kurtzman, 2000). The presence of additional strains in the species from the ambrosia beetle $X$. politus in this study provides further evidence that $C$. mycetangii is a common yeast that is widely associated with ambrosia beetles. On the other hand, only one strain of Pichia hampshirensis has been described; this strain, NRRL YB- $4128^{\mathrm{T}}\left(=\mathrm{CBS} 7208^{\mathrm{T}}\right)$, was isolated from frass on dead cut oak in 1956 and was reclassified recently as a member of the genus Wickerhamomyces along with many other related Pichia species (Kurtzman, 1987, 1998; Kurtzman et al., 2008). Strains ATCC 62896 and 62897 are the first additional strains of W. hampshirensis to be described since its initial description (Kurtzman, 1987) and were also isolated from beetle galleries on oak trees. Phylogenetically, W. hampshirensis and C. mycetangii were placed in a clade with many other insect-associated taxa (Fig. 2, clade C). Species near C. mycetangii, e.g. Lindnera (=Pichia) fabianii, Lindnera (=Pichia) mississippiensis, Lindnera (=Pichia) americana, Lindnera (=Pichia) bimundalis and Candida maritima have often been isolated either directly from insects or from their associated sources (Kurtzman, 1998; Meyer et al., 1998). The two undescribed Candida strains in the clade, JW01-7-11-1-2-y3 and BG01-7-26-007A-3-1, were also isolated from a bark beetle and a passalid, respectively (Suh et al., 2005). 
Strain ATCC 62895 was identified as a member of the ambrosia yeast species Saccharomycopsis microspora, although it showed some minor variations from the type strain of the species in SSU and LSU rDNA sequences and in some physiological characteristics (Table 1; Fig. 2). The species was originally described as a member of Pichia for the yeasts isolated from a bark beetle, Crossotarsus wollastoni (Curculionidae: Scolytinae), but was later reclassified in the genus Saccharomycopsis (Batra, 1971; Kurtzman, 1999). Interestingly, its close sister Saccharomycopsis synnaedendra and two undescribed Candida strains in the same clade, JW017-11-1-4-y3 and JW01-7-11-1-2-y1, were also isolated directly from bark beetles or from their tunnels in wood materials (clade A in Fig. 2; van der Walt \& Scott, 1971; Suh et al., 2005).

The novel species C. xyloterini sp. nov., described here to accommodate strain ATCC $62898^{\mathrm{T}}$, was a close sister taxon of $O$. dorogensis and Ogataea (=Pichia) kodamae, and was placed in a clade with many other species of the genus Ogataea and related Candida species that can be characterized by their ability to assimilate methanol as sole carbon source (Fig. 2, clade B). Strain ATCC $62898^{\mathrm{T}}$ was the only methanol-assimilating strain among the ambrosia yeasts reported here (Table 1). Many methylotrophic yeasts, e.g. $O$. dorogensis, O. kodamae, Ogataea (=Pichia) trehaloabstinens and Ogataea (=Pichia) zsoltii, have often been found in rotten wood material or insect associated plant sources. This association may correspond to the fact that methanol can be derived from the methoxy groups present in wood lignin (De Koning \& Harder, 1992; Péter et al., 2003). Very recently, several additional species in the genus Ogataea have been described, i.e. Ogataea ganodermae, Ogataea paradorogensis, Ogataea neopini and Ogataea corticis (Ji \& Bai, 2008; Nagatsuka et al., 2008; Nakase et al., 2008). Among these species, $O$. paradorogensis, isolated from galleries of ambrosia beetles in Japan, showed a close phylogenetic relationship with C. xyloterini sp. nov. (data not shown). However, the two species can be clearly distinguished by more than $1 \%$ variation in the sequences of the ITS and D1/ D2 region of the LSU rDNA and by several physiological characteristics (Nakase et al., 2008). Species of the genus Ambrosiozyma are well known yeasts associated with the ambrosia beetles (e.g. van der Walt, 1972; Smith, 1998). Several novel species of the genera Ambrosiozyma and Candida, i.e. Ambrosiozyma kamigamensis, Ambrosiozyma neoplatypodis, C. kashinagacola, C. pseudovanderkliftii and Candida vanderkliftii, have been reported recently from galleries of the ambrosia beetle, Platypus quercivorus (Coleoptera: Platypodidae), on oak trees (Endoh et al., 2008a, b). However, those Ambrosiozyma species and related mitosporic yeasts could be distinguished phylogenetically from C. xyloterini sp. nov. and other species in the Ogataea clade, and formed a sister group to the clade (Fig. 2). The diversity of yeasts associated with ambrosia beetles indicates that such a partnership is probably functionally based, not taxonomically determined.

C. palmyrensis sp. nov., described here to accommodate strain ATCC $62899^{\mathrm{T}}$, was phylogenetically distinct from any other ambrosia yeasts studied (Fig. 2). The species constituted an independent branch with $C$. sophiae-reginae and was placed in a clade that included species of Debaryomyces and related Candida spp. (Fig. 2, clade D). Although C. sophiae-reginae was the closest taxon to $C$. palmyrensis sp. nov. among the yeast species currently recognized, phylogenetically, the two were not close sisters based on the evolutionary rate, as shown by branch length (Fig. 2). Many gut yeasts isolated from a variety of beetles were placed in this Debaryomyces/Lodderomyces clade near Candida albicans, Pichia guilliermondii and Pichia stipitis (Suh \& Blackwell, 2004; Suh et al., 2003, 2008); however, those yeasts were not significantly related to C. palmyrensis sp. nov. Finding additional taxa near C. palmyrensis sp. nov. will help in the understanding of the phylogeny and ecology of this mitosporic yeast.

\section{Acknowledgements}

We are extremely grateful to Drs J. O. Haanstad and D. M. Norris who deposited the materials at ATCC Mycology Collection, and Janice Houseknecht, Pushpa Gujjari, Eric Emerick and Erica Hart who helped to characterize the yeasts. We also acknowledge Drs Marian McKee and Brian Beck for critical reading of the manuscript. This work was supported in part by National Science Foundation Grants DBI-0548684.

\section{References}

Altschul, S. F., Gish, W., Miller, W., Myers, E. W. \& Lipman, D. J. (1990). Basic local alignment search tool. J Mol Biol 215, 403410.

Barnett, J. A., Payne, R. W. \& Yarrow, D. (2000). Yeasts: Characteristics and identification, 3rd edn. Cambridge: Cambridge University Press.

Batra, L. R. (1966). Ambrosia fungi: extent of specificity to ambrosia beetles. Science 153, 193-195.

Batra, L. R. (1971). Two new hemiascomycetes: Pichia crossotarsi and P. microspora. Mycologia 63, 994-1001.

De Koning, W. \& Harder, W. (1992). Methanol-utilizing yeasts. In Methane and Methanol Utilizers, pp. 207-244. Edited by J. C. Murell \& H. Dalton. New York: Plenum Press.

Endoh, R., Suzuki, M. \& Benno, Y. (2008a). Ambrosiozyma kamigamensis sp. nov. and A. neoplatypodis sp. nov., two new ascomycetous yeasts from ambrosia beetle galleries. Antonie van Leeuwenhoek 94, 365-376.

Endoh, R., Suzuki, M., Benno, Y. \& Futai, K. (2008b). Candida kashinagacola sp. nov., C. pseudovanderkliftii sp. nov. and $C$. vanderkliftii sp. nov., three new yeasts from ambrosia beetleassociated sources. Antonie van Leeuwenhoek 94, 389-402.

Haanstad, J. O. \& Norris, D. M. (1985). Microbial symbiotes of the ambrosia beetle Xyloterinus politus. Microb Ecol 11, 267-276.

Harrington, T. C. (2005). Ecology and evolution of mycophagous bark beetles and their fungal partners. In Insect-fungal associations, pp. 257-291. Edited by F. E. Vega \& M. Blackwell. New York: Oxford University Press.

Hausner, G., Reid, J. \& Klassen, G. R. (1993). On the subdivision of Ceratocystis sensu lato, based on partial ribosomal DNA sequences. Can J Bot 71, 52-63. 
Ji, Z.-H. \& Bai, F.-Y. (2008). Ogataea ganodermae sp. nov., a methanolassimilating yeast species isolated from basidiocarps of Ganoderma sp. Int J Syst Evol Microbiol 58, 1502-1506.

Jindamorakot, S., Limtong, S., Yongmanitchai, W., Tuntirungkij, M., Potacharoen, W., Kawasaki, H. \& Nakase, T. (2007). Two new anamorphic yeasts, Candida thailandica sp. nov. and Candida lignicola sp. nov., isolated from insect frass in Thailand. FEMS Yeast Res 7, 1409-1414.

Kurtzman, C. P. (1987). Two new species of Pichia from arboreal habitats. Mycologia 79, 410-417.

Kurtzman, C. P. (1998). Pichia E.C. Hansen emend. Kurtzman. In The Yeasts, a Taxonomic Study, 4th edn, pp. 273-352. Edited by C. P. Kurtzman \& J. W. Fell. Amsterdam: Elsevier.

Kurtzman, C. P. (1999). Two new members of the Saccharomycopsis clade: Saccharomycopsis microspora, comb. nov. and Candida lassenensis, sp. nov. Mycotaxon 71, 241-250.

Kurtzman, C. P. (2000). Four new yeasts in the Pichia anomala clade. Int J Syst Evol Microbiol 50, 395-404.

Kurtzman, C. P. \& Fell, J. W. (1998). The Yeasts, a Taxonomic Study, 4th edn. Amsterdam: Elsevier.

Kurtzman, C. P. \& Robnett, C. J. (1998). Identification and phylogeny of ascomycetous yeasts from analysis of nuclear large subunit (26S) ribosomal DNA partial sequences. Antonie van Leeuwenhoek 73, 331371.

Kurtzman, C. P., Robnett, C. J. \& Basehoar-Powers, E. (2008). Phylogenetic relationships among species of Pichia, Issatchenkia and Williopsis determined from multigene sequence analysis, and the proposal of Barnettozyma gen. nov., Lindnera gen. nov. and Wickerhamomyces gen. nov. FEMS Yeast Res 8, 939-954.

Lee, S. B. \& Taylor, J. W. (1990). Isolation of DNA from fungal mycelia and single spores. In PCR Protocols - a guide to methods and applications, pp. 282-287. Edited by M. A. Innis, D. H. Gelfand, J. J. Sninsky \& T. J. White. San Diego, CA: Academic Press.

Limtong, S., Srisuk, N., Yongmanitchai, W., Yurimoto, H. \& Nakase, T. (2008). Ogataea chonburiensis sp. nov. and Ogataea nakhonphanomensis sp. nov., thermotolerant, methylotrophic yeast species isolated in Thailand, and transfer of Pichia siamensis and Pichia thermomethanolica to the genus Ogataea. Int J Syst Evol Microbiol 58, 302-307.

Meyer, S. A., Payne, R. W. \& Yarrow, D. (1998). Candida Berkhout. In The Yeasts, a Taxonomic Study, 4th edn, pp. 454-573. Edited by C. P. Kurtzman \& J. W. Fell. Amsterdam: Elsevier.

Nagatsuka, Y., Saito, D. \& Sugiyama, J. (2008). Ogataea neopini sp. nov. and $O$. corticis sp. nov., with the emendation of the ascomycete yeast genus Ogataea, and transfer of Pichia zsoltii, $P$. dorogensis, and $P$. trehaloabstinens to it. J Gen Appl Microbiol 54, 353-365.

Nakase, T., Ninomiya, S., Imanishi, Y., Nakagiri, A., Kawasaki, H. \& Limtong, S. (2008). Ogataea paradorogensis sp. nov., a novel methylotrophic ascomycetous yeast species isolated from galleries of ambrosia beetles in Japan, with a close relation to Pichia dorogensis. J Gen Appl Microbiol 54, 377-383.

Péter, G., Tornai-Lehoczki, J., Fülöp, L. \& Dlauchy, D. (2003). Six new methanol assimilating yeast species from wood material. Antonie van Leeuwenhoek 84, 147-159.

Smith, M. T. (1998). Ambrosiozyma van der Walt. In The Yeasts, a Taxonomic Study, 4th edn, pp. 129-133. Edited by C. P. Kurtzman \& J. W. Fell. Amsterdam: Elsevier.

Suh, S.-O. \& Blackwell, M. (2004). Three new beetle-associated yeasts in the Pichia guilliermondii clade. FEMS Yeast Res 5, 87-95.

Suh, S.-O., Marshall, C., McHugh, J. V. \& Blackwell, M. (2003). Wood ingestion by passalid beetles in the presence of xylose-fermenting gut yeasts. Mol Ecol 12, 3137-3145.

Suh, S.-O., McHugh, J. V., Pollock, D. D. \& Blackwell, M. (2005). The beetle gut: a hyperdiverse source of novel yeasts. Mycol Res 109, 261265.

Suh, S.-O., Nguyen, N. H. \& Blackwell, M. (2008). Yeasts isolated from plant-associated beetles and other insects: seven novel Candida species near Candida albicans. FEMS Yeast Res 8, 88-102.

Swofford, D. L. (2002). PAUP* ${ }^{*}$ phylogenetic analysis using parsimony ( ${ }^{*}$ and other methods), version 4.0b10. Sinauer Associates, Sunderland, Massachusetts, USA.

Tatusova, T. A. \& Madden, T. L. (1999). BLAST 2 sequences - a new tool for comparing protein and nucleotide sequences. FEMS Microbiol Lett 174, 247-250.

Thompson, J. D., Gibson, T. J., Plewniak, F., Jeanmougin, F. \& Higgins, D. G. (1997). The CLUSTAL_X windows interface: flexible strategies for multiple sequence alignment aided by quality analysis tools. Nucleic Acids Res 25, 4876-4882.

van der Walt, J. P. (1972). The yeast genus Ambrosiozyma gen. nov. (ascomycetes). Mycopathol Mycol Appl 46, 305-316.

van der Walt, J. P. \& Scott, D. B. (1971). Saccharomycopsis synnaedendra, a new yeast from South African insect sources. Mycopathol Mycol Appl 44, 101-106.

White, T. J., Bruns, T., Lee, S. \& Taylor, J. (1990). Amplification and direct sequencing of fungal ribosomal RNA genes for phylogenetics. In PCR Protocols - a guide to methods and applications, pp. 315-322. Edited by M. A. Innis, D. H. Gelfand, J. J. Sninsky \& T. J. White. San Diego, CA: Academic Press.

Yamada, Y., Maeda, K. \& Mikata, K. (1994). The phylogenetic relationships of the hat-shaped ascospore-forming, nitrate-assimilating Pichia species, formerly classified in the genus Hansenula Sydow et Sydow, based on the partial sequences of $18 \mathrm{~S}$ and $26 \mathrm{~S}$ ribosomal RNAs (Saccharomycetaceae): the proposal of three new genera, Ogataea, Kuraishia, and Nakazawaea. Biosci Biotechnol Biochem 58, 1245-1257.

Yarrow, D. (1998). Methods for the isolation, maintenance and identification of yeasts. In The Yeasts, a Taxonomic Study, 4th edn, pp. 77-100. Edited by C. P. Kurtzman \& J. W. Fell. Amsterdam: Elsevier. 